DOI: 10.17951/lrp.2019.38.3.255-269

\author{
AgnieszKa Bochniarz \\ Uniwersytet Marii Curie-Skłodowskiej w Lublinie \\ ORCID - 0000-0002-5675-3314 \\ AnNa Grabowiec \\ Uniwersytet Marii Curie-Skłodowskiej w Lublinie \\ ORCID - 0000-0002-2096-649X
}

\title{
UCZEŃ ZDOLNY W RZECZYWISTOŚCI POLSKIEJ SZKOŁY
}

\begin{abstract}
Streszczenie: Potencjał osób zdolnych stanowi niezwykle ważny zasób każdej społeczności. Istotne jest więc, aby w świadomości wszystkich uczestników procesów edukacyjnych pojawiła się na stałe kategoria „zdolności” i „ucznia zdolnego” jako wartości. W artykule przedstawiono problematykę dotyczącą pracy z uczniem zdolnym. W części wstępnej przybliżono pojęcie i charakterystykę uczniów zdolnych, ze zwróceniem uwagi na syndrom nieadekwatnych osiągnięć oraz zaburzenia rozwojowe, takie jak asynchronia rozwojowa. Wskazano na rolę i zadania szkoły w kontekście szczególnego wsparcia, jakie instytucja ta powinna zapewnić uzdolnionym uczniom. W artykule zaprezentowano ponadto wyniki badań dotyczących opieki nad uczniami zdolnymi w polskich szkołach. Na koniec przedstawiono przykłady „dobrych praktyk” wspomagających działania szkoły w projektowaniu edukacji uczniów zdolnych.
\end{abstract}

Słowa kluczowe: uczeń zdolny, szkoła, nauczyciel, kształcenie uczniów zdolnych, indywidualny program nauki, indywidualny tok nauki

Wprawdzie ze względów praktycznych systemy edukacji muszą być tworzone w taki sposób, aby zapewnić kształcenie dostosowane do większości dzieci i młodzieży, zawsze jednak będą istnieć grupy, które mają specjalne potrzeby, i dla których trzeba wprowadzać specjalne rozwiązania. Jedną z takich grup są dzieci i młodzież o dużych zdolnościach [...].

Recommendation 1248 (1994). Education for gifted children 


\section{WPROWADZENIE}

W dobie szybko dokonujących się przemian społecznych, ekonomicznych i politycznych, postępu w dziedzinie nauki i techniki oraz wzrastającej roli innowacyjności i konkurencyjności na rynku pracy promowanie jednostek uzdolnionych nabiera szczególnego znaczenia. Dostrzegły to państwa Wspólnoty Europejskiej, uznając w czerwcu 2002 roku edukację grupy uczniów zdolnych za priorytetowe zadanie polityki edukacyjnej państw Unii Europejskiej (za: Stańczak 2009, s. 7).

W literaturze przedmiotu znajdujemy wiele różnorodnych definicji terminu „uczeń zdolny”, co wynika między innymi z wieloznaczności terminu „zdolności”. Najczęściej o uczniach zdolnych mówimy w odniesieniu do jednostek, które pod względem zdolności intelektualnych przewyższają swoich rówieśników. Erwin Gondzik (za: Piotrowski 2001, s. 335) za ucznia zdolnego uznaje jednostkę o wysokim poziomie inteligencji, szerokich zainteresowaniach, wysokim poziomie samokrytycyzmu i pracowitości oraz wyobraźni twórczej. Zdaniem Marii Tyszkowej (1993, s. 864) uczeń zdolny to jednostka, która przejawia wysoki poziom zdolności ogólnych lub dysponuje określoną zdolnością specjalną w sferze działalności umysłowej. Według Ellen Winner (za: Landau 2005, s. 63-64) w definiowaniu ucznia zdolnego największą rolę odgrywają trzy aspekty: szybkość uczenia się, stosunek do nauki i pomysłowość. Zdaniem autorki uczeń zdolny to dziecko o nad wiek rozwiniętej dojrzałości i zdolnościach, żądne wiedzy, motywowane od wewnątrz, zdolne do maksymalnej koncentracji i uczące się szybciej od rówieśników, zgodnie z własnymi pomysłami, wykraczającymi poza schematy szkolnego przyswajania wiedzy.

Tadeusz Lewowicki (1986, s. 62-63), dokonawszy przeglądu wielu definicji pojęcia ucznia zdolnego, opracował własną definicję, stwierdzając, że ucznia można uznać za zdolnego, jeśli przejawia przynajmniej jedną z następujących cech:

1) wysoki poziom zdolności ogólnych, inteligencji;

2) wysoki poziom zdolności specjalnych (uzdolnień), np. artystycznych, sportowych, organizacyjnych lub poznawczych, związanych często z przedmiotami szkolnymi;

3) wysokie osiągnięcia lub potencjał pozwalający na takie osiągnięcia;

4) osiągnięcia oryginalne i twórcze lub możliwości takich osiągnięć.

Autor operuje jednocześnie kilkoma wyznacznikami zdolności, co pozwala włączyć do grupy uczniów zdolnych znacznie większą, niż w przypadku innych definicji, liczbę uczniów.

Niniejszy artykuł jest próbą odpowiedzi na pytanie: czy polska szkoła wspiera uczniów zdolnych? Zaprezentowane zostaną wyniki badań dotyczących form pomocy udzielanej tej grupie uczniów oraz przedstawione zadania szkoły i na- 
uczycieli jako organizatorów procesu kształcenia ukierunkowanego na rozwój ucznia zdolnego. Na koniec wskazane zostaną przykłady praktyk o charakterze programowym, organizacyjnym i metodycznym, wspierających działania szkoły w edukacji uczniów zdolnych.

\section{SYLWETKA UCZNIA ZDOLNEGO}

Dzieci zdolne bardzo wcześnie ujawniają wysoki poziom rozwoju zdolności intelektualnych lub kierunkowych. W próbach określenia cech charakteryzujących ucznia zdolnego autorzy (zob. Bieluga 2003; Nęcka 2005; Dyrda 2007; Limont 2010; Dąbrowska i in. 2013; Fechner-Sędzicka 2013; Uszyńska-Jarmoc i in. 2014; Gwiazdowska-Stańczak, Sękowski 2018) zwracają uwagę na takie właściwości, jak:

- wysoka aktywność i ciekawość poznawcza - dzieci zdolne są szczególnie dociekliwe, bardzo wnikliwie interesują się jakimś zagadnieniem, jak też sprawami ogólnymi;

- zdolność do efektywnego uczenia się rzeczy nowych;

- wysoki poziom umiejętności myślenia abstrakcyjnego;

- szerokie zainteresowania - zainteresowania dzieci zdolnych są bardzo pogłębione i zwykle dotyczą poważnych problemów, którymi ich rówieśnicy się nie interesują;

- wrażliwość na problemy i wytrwałość w ich rozwiązywaniu;

- krytyczny stosunek do informacji i dążenie do ich weryfikowania;

- spostrzegawczość - dzieci zdolne zauważają niemal najdrobniejsze szczegóły lub subtelne różnice między obiektami;

- koncentracja i wytrwałość - dzieci zdolne łatwo i na długi czas się koncentrują, są bardzo wytrwałe w swoich działaniach i odporne na zmęczenie;

- silna motywacja wewnętrzna i samodzielność w zdobywaniu wiedzy;

- zamiłowanie do czytania - dzieci zdolne bardzo dużo i szybko czytają, ze zrozumieniem i umiejętnością zreferowania przeczytanych treści;

- bogate słownictwo;

- oryginalność w myśleniu i działaniu;

- wysoki poziom zdolności twórczych;

- samokrytycyzm - dzieci zdolne są bardzo ambitne, stawiają sobie wysokie wymagania i krytycznie odnoszą się do własnych osiągnięć;

- przeżywanie satysfakcji z rozwiązywania problemów i pokonywania trudności intelektualnych;

- wysoka i adekwatna samoocena; 
- dojrzałość - dzieci zdolne często dorównują osobom dorosłym poziomem prowadzonej rozmowy, posługując się wyszukanym słownictwem i uzasadnionymi argumentami w dyskusji;

- preferowanie towarzystwa dorosłych lub starszych kolegów, przy równoczesnej umiejętności przystosowania się do grupy rówieśniczej;

- zdolności przywódcze;

- często krytyczne nastawienie do szkolnego procesu dydaktyczno-wychowawczego.

Czasami dzieci zdolne postrzegane są przez otoczenie jako jednostki oryginalne, a nawet ekscentryczne, zachowujące się dziwacznie, trudne w kontaktach i słabo przystosowane społecznie. Zdarza się również, że odbierane są jako „nienormalne", a nawet opóźnione intelektualnie, ponieważ drastycznie odbiegają od przeciętności. Jednak z badań wynika, że większość zdolnych dzieci to jednostki emocjonalnie zrównoważone, dobrze przystosowane i popularne wśród rówieśników (za: Nęcka 2005, s. 168).

Uczniów zdolnych nie można traktować jako grupy jednorodnej, o takich samych potrzebach. Dzieci te bowiem różnią się od siebie nie tylko rodzajem uzdolnień, lecz także poziomem ich rozwoju (Cybis i in. 2012, s. 9). Często występującą cechą u dzieci wybitnie zdolnych jest asynchronia rozwojowa, która polega na tym, że sfera emocjonalna, społeczna lub/i ruchowa mogą rozwijać się wolniej $\mathrm{w}$ porównaniu do sfery poznawczej. Przyczyną asynchronii rozwojowej u dzieci zdolnych jest wielość, różnorodność oraz intensywność zewnętrznych i wewnętrznych doświadczeń, które odbiegając od norm rozwojowych, prowadzą do tego, że rozwój osobowości nie przebiega harmonijnie. Towarzyszyć temu może stres, który z kolei prowadzi do pojawienia się problematycznych zachowań, zaniżonych wyników w nauce czy nawet depresji (Limont 2010, s. 88-89).

Coraz więcej uczniów o potencjalnie wysokim poziomie zdolności osiąga niskie wyniki w uczeniu się i funkcjonuje poniżej własnych możliwości. Literatura przedmiotu podaje, że około 50\% uczniów zdolnych nie jest $\mathrm{w}$ stanie $\mathrm{w}$ pełni wykorzystać swoich możliwości i zdolności związanych z potencjałem intelektualnym i twórczym, osiągając niskie wyniki w nauce. Grupa ta została określona jako uczniowie z syndromem nieadekwatnych osiągnięć i ma zróżnicowaną charakterystykę (zob. Limont 2010, s. 252; Dąbrowska i in. 2013, s. 24).

Źródeł niepowodzeń w nauce dzieci z syndromem nieadekwatnych osiągnięć należy upatrywać $w$ trzech grupach czynników. Pierwsza grupa wiąże się ze środowiskiem życia dziecka, a konkretnie ze skomplikowaną sytuacją rodzinną, na którą mogą składać się między innymi warunki socjoekonomiczne, klimat emocjonalny $\mathrm{w}$ rodzinie, postawy rodzicielskie, styl wychowania i więzi z poszczególnymi członkami rodziny, sytuacje stresogenne w rodzinie, jak rozwód czy 
separacja rodziców. Grupa ta obejmuje ponadto czynniki związane z przynależnością do mniejszości religijnych, etnicznych i językowych oraz różnego rodzaju stereotypy społeczne, negatywnie wpływające na rozwój zdolności. Druga grupa przyczyn niskich wyników uczniów zdolnych to właściwości somatyczne i psychiczne dziecka, które mają związek z jego rozwojem intelektualnym i emocjonalnym, z dysfunkcjami w układzie nerwowym, z występowaniem chorób przewlekłych i wad fizycznych. Ostatnią grupę czynników należy wiązać z procesem nauczania. Wymienić tu można programy nauczania niedostosowane do potrzeb i możliwości uczniów, brak zajęć kompensacyjno-wychowawczych, niewłaściwie dobrane metody nauczania i formy pracy lub też złą atmosferę w szkole (Limont 2010, s. 253-254).

Uczniowie z syndromem nieadekwatnych osiągnięć to dzieci z niskim poczuciem własnej wartości, niską oceną samoskuteczności, wycofujące się szybko z aktywności, niepodejmujące nowych zadań i wyzwań, nieufne, impulsywne, pesymistyczne, nieprzychylnie nastawione do otoczenia, bez motywacji do nauki, sukces łączące z przypadkiem, a niepowodzenie z brakiem zdolności. Ponadto charakteryzuje je brak wytrwałości i samokontroli, niska odporność na stres, poczucie winy z powodu niespełnienia oczekiwań bliskich oraz częste wykorzystywanie mechanizmów obronnych (Dyrda 2000, s. 41; Limont 2010, s. 255).

Inną grupą uczniów zdolnych są dzieci, które charakteryzują się jednocześnie określonymi deficytami rozwojowymi. Stanowią one 10-15\% uczniów zdolnych i określane są jako podwójnie wyjątkowe. Dzieci te z jednej strony są uzdolnione w sferze poznawczej lub/i pozapoznawczej, a z drugiej posiadają pewne ograniczenia, które utrudniają im naukę. Do grupy tej należą: uczniowie z niepełnosprawnością fizyczną, z problemami w mówieniu, niedowidzące, niedosłyszące, z zaburzeniami emocjonalnymi, z dysleksją, z chorobami przewlekłymi, z nadpobudliwością ruchową, $\mathrm{z}$ deficytem uwagi czy z zespołem Aspergera. Wymagają one opracowania specjalnych programów kształcenia, strategii nauczania i wychowania, które powinny uwzględniać ich zdolności oraz posiadane deficyty, dzięki czemu ułatwi im to proces uczenia (Fechner-Sędzicka 2013, s. 22; Limont 2010, s. 235).

\section{KSZTAŁCENIE UCZNIÓW ZDOLNYCH}

W obowiązującym prawie znaleźć można szereg zapisów, które wskazują na konieczność rozpoznawania i zaspokajania indywidualnych potrzeb, możliwości i aspiracji uczniów zdolnych. 


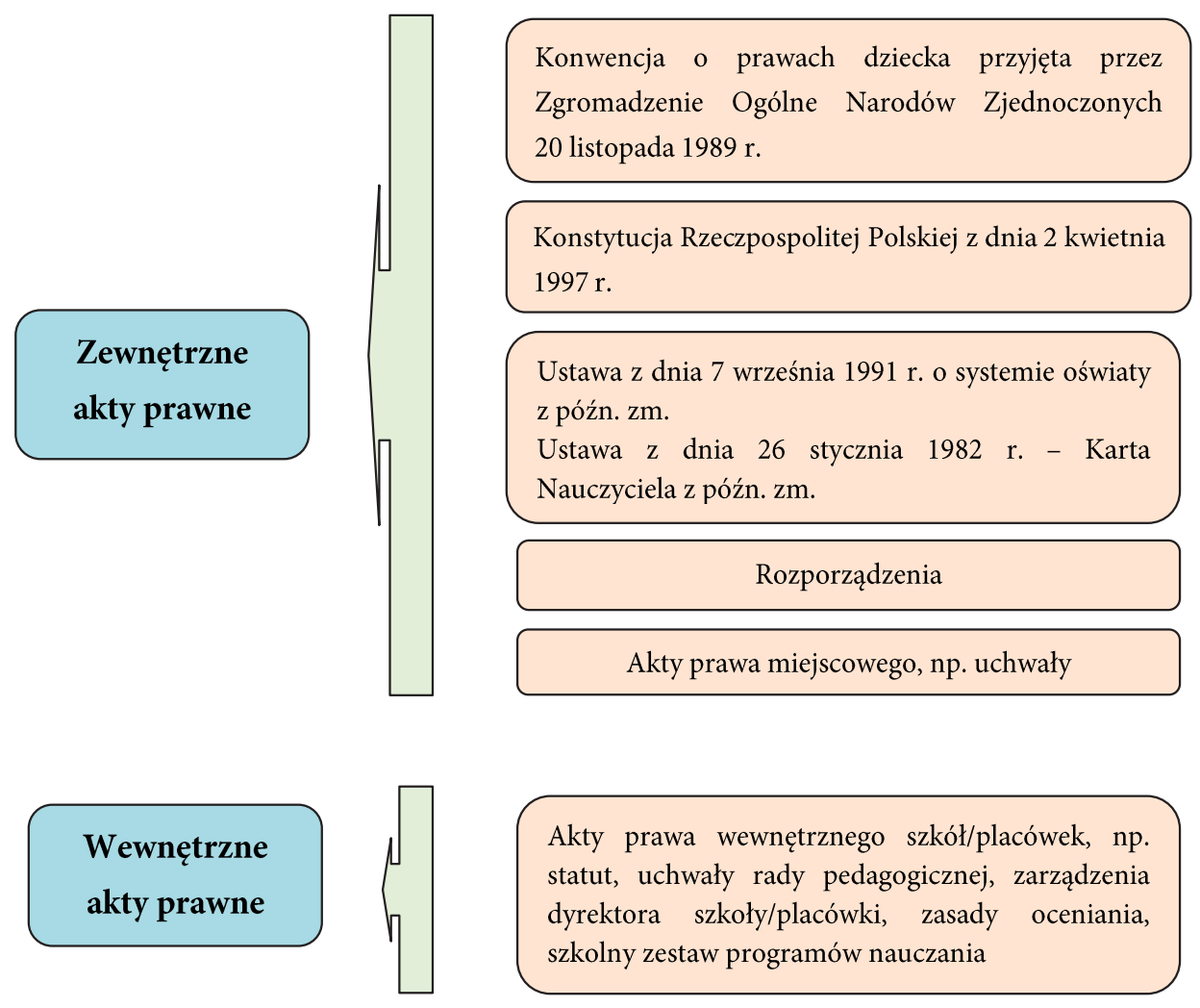

Rys. 1. Obowiązujące zewnętrzne i wewnętrzne akty prawne

Źródło: T. Dąbrowska i in., 2013, Model pracy z uczniem zdolnym w gimnazjum, Ośrodek Rozwoju Edukacji, Warszawa, s. 12.

Kwestię kształcenia uczniów zdolnych w naszym kraju reguluje ustawa z dnia 7 września 1991 roku o systemie oświaty (tekst jedn. Dz.U. z 2018 r., poz. 1457) odnosząca się do wskazań Międzynarodowej Konwencji Praw Dziecka, której art. 29 głosi: „[...] nauka dziecka będzie ukierunkowana na rozwijanie w jak najpełniejszym zakresie osobowości, talentów oraz zdolności umysłowych i fizycznych dziecka" (Konwencja o prawach dziecka, s. 210).

Zgodnie z Rozporządzeniem Ministra Edukacji Narodowej z dnia 9 sierpnia 2017 roku w sprawie warunków i trybu udzielania zezwoleń na indywidualny program lub tok nauki oraz organizacji indywidualnego programu lub toku nauki (Dz.U. z 2017 r., poz. 1569) w celu umożliwienia uczniowi rozwijania szczególnych uzdolnień dyrektor szkoły może zezwolić uczniowi na indywidualny program 
lub tok nauki. Organizację indywidualnego programu lub toku nauki oraz warunki i tryb udzielania zezwoleń na indywidualny program lub tok nauki zostały precyzyjnie określone rozporządzeniem Ministra Edukacji Narodowej i Sportu z dnia 19 grudnia 2001 roku w sprawie warunków i trybu udzielania zezwoleń na indywidualny program lub tok nauki oraz organizacji indywidualnego programu lub toku nauki (Dz.U. z 2002 r. Nr 3, poz. 28).

Indywidualny program nauki oznacza, że proces kształcenia może przebiegać na podstawie programu będącego modyfikacją programu dopuszczonego do użytku szkolnego. Umożliwia on pogłębienie standardowych treści programu nauczania, dostosowanie wymagań edukacyjnych z przedmiotów nieobjętych indywidualnym programem nauki do indywidualnych potrzeb i możliwości uczniów uzdolnionych jednokierunkowo, kształcenie w zakresie jednego zajęcia edukacyjnego lub kilku z nich z maksymalnym uwzględnieniem zainteresowań, możliwości i potrzeb ucznia zdolnego, efektywną indywidualizację na każdym etapie kształcenia i w każdym typie szkoły, kształcenie dostosowane do zdolności, zainteresowań i możliwości edukacyjnych konkretnego ucznia (Fechner-Sędzicka 2013, s. 70).

Z kolei indywidualny tok nauki daje uczniowi możliwość kształcenia się $\mathrm{w}$ innym niż klasowo-lekcyjnym systemie nauczania oraz bycia promowanym i klasyfikowanym w odmiennym, niż powszechnie obowiązującym, cyklu. Stanowi efektywną formę pracy z uczniem zdolnym, ponieważ umożliwia realizację treści kształcenia $\mathrm{w}$ krótszym czasie, przyspiesza kształcenie $\mathrm{w}$ obszarze wybranego przedmiotu lub grup przedmiotów, uczestniczenie w lekcjach w klasie programowo wyższej, w innej szkole, naukę treści we własnym tempie, realizację w ciągu jednego roku szkolnego programu nauczania z zakresu dwóch lub więcej klas, możliwość ukończenia nauki w skróconym czasie, dostosowanie wymagań z przedmiotów nieobjętych indywidualnym tokiem nauki do potrzeb i możliwości uczniów o wybitnych uzdolnieniach jednokierunkowych, realizację programu w części lub w całości we własnym zakresie, realizację indywidualnego toku nauki zgodnie z potrzebami konkretnego ucznia i opracowanego specjalnie dla niego (Fechner-Sędzicka 2013, s. 72).

Zarówno indywidualny program, jak i tok nauki może dotyczyć jednego, kilku lub też wszystkich obowiązujących daną klasę zajęć edukacyjnych. Głównym celem indywidualnego programu lub toku nauki jest umożliwienie uczniom zdolnym rozwoju ich szczególnych zdolności i zainteresowań poprzez dostosowanie zakresu treści oraz tempa kształcenia do indywidualnych potrzeb i możliwości dziecka. 


\section{RZECZYWISTOŚĆ SZKOLNA}

Rozważając sytuację ucznia zdolnego w szkole, należy zadać pytanie, czy obecność w klasie takiego dziecka jest dla nauczyciela wyzwaniem i motywacją do dalszej pracy, czy też problemem, oraz jaki faktycznie jest wkład szkoły w proces rozwoju dziecka zdolnego.

W 2007 roku Najwyższa Izba Kontroli opublikowała raport dotyczący opieki nad uczniami zdolnymi w Polsce. Niestety rezultaty kontroli przeprowadzonej w 74 szkołach publicznych na terenie 12 województw wykazały niewielki zakres obejmowania uczniów o ponadprzeciętnych zdolnościach indywidualnym programem lub tokiem nauki. Negatywnie zostały ocenione zakres oraz efekty działań większości skontrolowanych szkół, dotyczące identyfikacji uczniów zdolnych. Działania te polegały głównie na analizie wyników kształcenia związanej z klasyfikacją semestralną i roczną. Prawie $80 \%$ nauczycieli zatrudnionych w objętych kontrolą szkołach przyznało, że nigdy w swojej praktyce zawodowej nie realizowało indywidualnego programu nauczania, a szkoleniami dotyczącymi kwestii kształcenia uczniów zdolnych zostało objęte zaledwie 7,3\% pracowników pedagogicznych tych szkół (Najwyższa Izba Kontroli 2007, s. 2-5).

W tym kontekście warto również przytoczyć niektóre wyniki z przygotowanego w 2010 roku przez Helsińską Fundację Praw Człowieka raportu z monitoringu dotyczącego prawa do nauki dzieci o specjalnych potrzebach edukacyjnych. Badania zostały przeprowadzone w 121 szkołach podstawowych i gimnazjach w województwach: mazowieckim, podlaskim, kujawsko-pomorskim i zachodnio-pomorskim, śląskim, łódzkim i lubuskim. Z dokonanych w raporcie analiz wynika, że w blisko 96\% badanych szkół nie realizuje się indywidualnego toku nauki z żadnym uczniem. Na łączną liczbę 29711 uczniów realizujących obowiązek szkolny z indywidualnego toku nauki korzysta 0,02\% dzieci i młodzieży. Oferta działań wspierających uczniów nie wykracza poza koła zainteresowań i konsultacje indywidualne $z$ nauczycielem, przy czym skierowane są one do wszystkich zainteresowanych uczniów, a nie nastawione na konkretnego ucznia zdolnego. Tylko w 5 szkołach odbywały się zajęcia dodatkowe prowadzone przez specjalistów spoza szkoły (Ciechowski i in. 2010, s. 66-67).

Autorzy raportu podkreślają, że w polskich szkołach brakuje procedur, umożliwiających rozpoznanie uczniów o szczególnych uzdolnieniach. O zaklasyfikowaniu ucznia jako zdolnego decydują przede wszystkim jego wyniki w nauce, zaangażowanie na lekcjach oraz udział w olimpiadach przedmiotowych i konkursach (Ciechowski i in. 2010, s. 64-65).

Z badań pilotażowych przeprowadzonych przez autorki w kilku lubelskich gimnazjach i liceach w roku szkolnym 2017/2018 wynika, że w praktyce w polskim 
szkolnictwie nadal mało uwagi poświęca się uczniom zdolnym. Przejawia się to między innymi w tym, że:

- $\quad$ szkoły nie prowadzą w sposób świadomy i systematyczny identyfikacji zdolności uczniów;

- nauczyciele interesują się przede wszystkim zdolnościami poznawczymi uczniów;

- podstawowymi formami pracy z uczniem zdolnym są zajęcia pozalekcyjne, np. koła zainteresowań, oraz zajęcia organizowane w celu przygotowania do konkursów i olimpiad przedmiotowych;

- $\quad$ spośród lekcyjnych form pracy z uczniem zdolnym najczęściej nauczyciele wykorzystują pracę indywidualną, polegającą na stawianiu mu wyższych wymagań przy opracowywaniu poszczególnych zagadnień, zadawaniu trudniejszych prac domowych oraz zmianie kryteriów oceny takich uczniów;

- bardzo rzadko szkoły podejmują się indywidualnej pracy z uczniem poprzez indywidualny program i tok nauki.

Wyniki te są zbieżne z wynikami badań Agnieszki Hłobił (2010), Teresy Gizy (2006) i Małgorzaty Stańczak (2009). Zdaniem Stańczak (2009, s. 96) szkoły tworząc warunki rozwoju uczniów zdolnych w ramach oferowanych zajęć pozalekcyjnych, bazują na standardowych strategiach działań w tym zakresie. Jak zauważa autorka, założenia organizacyjne i metodykę kół zainteresowań jako główną formę zajęć pozalekcyjnych „opracowano pół wieku temu”.

Badania Hłobił (2010, s. 93, 95) przeprowadzone na terenie siedmiu koszalińskich masowych szkół gimnazjalnych pokazały, że żadna szkoła nie podjęła się indywidualnej pracy $\mathrm{z}$ uczniem zdolnym przez indywidualne programy nauki, kształcąc ucznia według programu dostosowanego do jego indywidualnych zainteresowań i potrzeb. W żadnej ze szkół dyrektor nie udzielał zgody na indywidualny tok nauczania, zarówno z powodu braku wniosków rodziców uczniów zdolnych, jak i braku opinii ze strony rad pedagogicznych i poradni psychologiczno-pedagogicznych, na podstawie których dopuszcza się taką możliwość. Głównym kryterium rozpoznawania przez nauczycieli uczniów zdolnych była ocena szkolna, uczestnictwo w olimpiadach i konkursach oraz obserwacja. Okazało się, że bardzo rzadko nauczyciele sięgają po fachową pomoc, np. psychologów.

Według Gizy (2006, s. 302-305) sytuacja edukacyjna uczniów zdolnych jest zdeterminowana jakością środowiska szkolnego, stąd też działania podejmowane przez szkoły sprowadzają się najczęściej do takich, które nie wymagają szczególnych zabiegów i nakładów. Przeprowadzone przez nią badania pokazały, że prawie połowa placówek nie stosuje żadnych form pomocy uczniom zdolnym, a nauczyciele nie znają pozaszkolnych możliwości wspierania takich uczniów. 
W selekcji uczniów zdolnych nauczyciele kierują się dwoma kryteriami: średnią ocen i rodzajem zaobserwowanych zdolności.

Przedstawione wyniki raportów i badań jednoznacznie wskazują, że kształcenie uczniów szczególnie uzdolnionych traktowane jest przez polskie szkoły w sposób marginalny. Zdaniem Beaty Dyrdy (2012, s. 307-310) poważnym problemem jest traktowanie wyników w nauce jako podstawowych wskaźników zdolności ucznia. Bardzo często widoczne jest przy tym odwoływanie się do potocznej wiedzy dotyczącej cech uczniów uzdolnionych, szczególnie zaś do opinii, że nie powinni oni sprawiać problemów natury wychowawczej. Zdarza się również, że szkoły nastawione są na wspieranie niektórych tylko zdolności, przez co proces identyfikacji zostaje sprowadzony do wyszukiwania uczniów dysponujących konkretnym profilem uzdolnień.

\section{ROLA NAUCZYCIELA I SZKOŁY}

W potocznej opinii jednostki zdolne nie potrzebują żadnego wsparcia i pomocy, gdyż niezależnie od warunków środowiskowych i stopnia zaspokojenia ich szczególnych potrzeb edukacyjnych znakomicie poradzą sobie w szkole i w życiu oraz rozwiną swój talent. Tymczasem praktyka edukacyjna wyraźnie wskazuje na znaczenie nauczyciela w procesie rozwoju zdolności ucznia (Limont, Cieślikowska 2004, s. 33-39).

Wielość zagrożeń rozwoju dzieci zdolnych implikuje konieczność przygotowania odpowiedniego modelu pracy z uczniem zdolnym, w którym wykorzystywane będą różne metody i formy edukacyjne, np. warsztaty i obozy, realizowanie wspólnych projektów i badań naukowych, wcześniejsze rozpoczynanie nauki, promocje śródroczne, ciekawe oferty zajęć pozalekcyjnych. W procesie rozwijania zdolności dzieci i młodzieży konieczne jest opracowanie właściwych programów interwencyjno-edukacyjnych, które rozwijałyby kompetencje i zaangażowanie nauczycieli, opiekunów, wychowawców i rodziców, dzięki czemu podmioty te będą $\mathrm{w}$ stanie między innymi właściwie identyfikować uzdolnienia oraz tworzyć warunki do ich rozwoju. W związku z tym, że jest to proces złożony, rozpoznawanie dzieci zdolnych powinno odbywać się na wszystkich etapach kształcenia, każdy bowiem etap edukacji jest dobrym momentem do tego, aby zainicjować przemyślane działania dla dobra ucznia zdolnego (Limont 2010, s. 30, 99).

Nauczyciele w procesie identyfikacji ucznia zdolnego powinni uwzględniać podejście holistyczne, obejmując rozpoznaniem wiele obszarów, a mianowicie: zainteresowania, predyspozycje, pasje dziecka, rodzaje i poziomy zdolności, mocne 
strony, możliwości i potencjał dziecka, słabsze strony, trudności i ograniczenia, motywację i zaangażowanie w zadanie, potrzeby, warunki środowiskowe (rodzina i rówieśnicy), jakość komunikacji, preferowany styl uczenia się, czynniki osobowościowe ucznia (Fechner-Sędzicka 2013, s. 27).

Działania podejmowane wobec uczniów zdolnych przez szkołę i jej partnerów jako wzajemnie powiązane i wpływające na siebie podmioty powinny być spójne i skuteczne, tylko wówczas bowiem mogą prowadzić do pozytywnych zmian w dziecku, wykorzystywania przez nie swego potencjału i rozwoju na miarę swoich możliwości (Dąbrowska i in. 2013, s. 107). Stymulowanie i wspieranie dziecka zdolnego przez środowisko szkolne i rodzinne to zapewnienie mu poczucia bezpieczeństwa, koncentrowanie się na dziecku, stosowanie aktywizujących metod i form pracy, zachęcanie do samodzielnego myślenia, motywowanie do działania czy zaspokajanie różnorodnych potrzeb, między innymi poznawczych, emocjonalnych i społecznych (Fechner-Sędzicka 2013, s. 15).

Nauczyciele powinni dysponować odpowiednią wiedzą i przygotowaniem $\mathrm{w}$ zakresie pracy z uczniem zdolnym, co oznacza rozpoznawanie jego potrzeb edukacyjnych, zachowań, będących oznaką uzdolnień ogólnych, kierunkowych i twórczych, opracowywanie programów wspierających i rozwijających uzdolnienia, współpracę z rodzicami, innymi nauczycielami i specjalistami (Dąbrowska i in. 2013, s. 21).

\section{PRZYKŁADY „DOBRYCH PRAKTYK” WSPOMAGAJACYCH DZIAŁANIA SZKOŁY W EDUKACJI UCZNIÓW ZDOLNYCH}

Na szczęście w praktyce edukacyjnej można odnaleźć przykłady dobrych praktyk, które mają wspomagać działania szkoły w projektowaniu edukacji uczniów zdolnych. Szczególną uwagę wzbudzają trzy propozycje projektów skierowanych do zdolnych uczniów: Dolnośląski System Wspierania Uzdolnień „zDolny Ślązak”, Projekt DiAMEnT oraz Warszawski System Wspierania Uczniów Uzdolnionych „Wars i Sawa” (Fechner-Sędzicka 2013, s. 40; Łukasiewicz-Wieleba, Baum 2015, s. 52-53).

Program Dolnośląski System Wspierania Uzdolnień „zDolny Ślązak” był jedną z pierwszych tego typu inicjatyw w Polsce. Realizowany jest od 1999 roku przez Dolnośląski Ośrodek Doskonalenia Nauczycieli we Wrocławiu we współpracy z Urzędem Marszałkowskim, Kuratorium Oświaty, Fundacją Edukacji Międzynarodowej i Uniwersytetem Wrocławskim. W projekcie tym zakłada się, że istnieje wiele różnych uzdolnień, a każdy uczeń może mieć ukryte zdolności, stąd ważne jest wspieranie rozwoju uczniów zdolnych w ich środowiskach, w tym wypadku 
w szkołach. Najistotniejszym punktem systemu jest Dolnośląska Sieć Szkół Wspierających Uzdolnienia - każda szkoła, która wstępuje do sieci, jest sprawdzana w zakresie stosowanych metod i form wspierania uzdolnień swoich uczniów. W szkołach tworzone są programy rozwijające zainteresowania i uzdolnienia uczniów, a następnie monitorowane i poddawane ocenie. Szkoły mają obowiązek współpracy ze sobą i dzielenia się przykładami dobrych praktyk. W ramach projektu organizowane są także konkursy „zDolny Ślązaczek” dla dzieci ze szkół podstawowych i „zDolny Ślązak Gimnazjalista” (Limont 2010, s. 172; Fechner-Sędzicka 2013, s. 43; Łukasiewicz-Wieleba, Baum 2015, s. 52-53).

Projekt DiAMEnT - Dostrzec i aktywizować możliwości, energię, talenty powstał z inicjatywy Zarządu Województwa Małopolskiego jako projekt innowacyjny w ramach Priorytetu IX Programu Operacyjnego Kapitał Ludzki. Realizowany był od 1 marca 2009 roku do 31 grudnia 2013 roku. Jego głównym celem było stworzenie systemu pracy z uczniami zdolnymi oraz zwiększenie ich szans na odniesienie sukcesu poprzez wspieranie rozwoju ich uzdolnień w zakresie myślenia twórczego, technologii informacyjno-komunikacyjnych, języka angielskiego, przedsiębiorczości i matematyki. W projekt zaangażowano wiele środowisk związanych z edukacją uczniów zdolnych, w tym pracowników uczelni, specjalistów z poradni psychologiczno-pedagogicznych, doradców metodycznych. Uczestnikom proponowana była praca metodą projektu oraz uczenie się przez rozwiązywanie problemów. Podczas zajęć zachęcano do odwagi w myśleniu, stawiano na pracę zespołową, samodzielność w myśleniu, kreatywność. W ramach projektu realizowano warsztaty i szkolenia dla nauczycieli i innych pracowników oświaty (Fechner-Sędzicka 2013, s. 40-41; Łukasiewicz-Wieleba, Baum 2015, s. 53-54).

Warszawski System Wspierania Uczniów Uzdolnionych „Wars i Sawa” jest programem adresowanym zarówno do dzieci i nauczycieli, jak i do rodziców. Jego główny cel sprowadza się do wczesnego wykrywania i wspomagania uzdolnień uczniów. Szkoły biorące udział w programie uzyskują wsparcie poradni psychologiczno-pedagogicznych w procesie identyfikacji uzdolnień, mają możliwość korzystania z oferty zajęć na uczelniach warszawskich bądź prowadzonych przez organizacje pozarządowe. Program zapewnienia również bogatą ofertę szkoleń dla nauczycieli. Kluczowym elementem programu było ustanowienie w 2009 roku Certyfikatu Prezydenta m.st. Warszawy WARS i SAWA, przyznawanego szkołom, które osiągnęły pożądany standard pracy w obszarze wspierania uczniów uzdolnionych. Warto podkreślić fakt, że program ten został wyróżniony poprzez umieszczenie go na międzynarodowej mapie talentów, tworzonej przez Europejskie Centrum Talentów (European Talent Centre) (Łukasiewicz-Wieleba, Baum 2015, s. 63-70) 


\section{PODSUMOWANIE}

Przedstawione rozważania na temat pracy z uczniem zdolnym pokazują, że kluczowa rola szkoły we wspieraniu rozwoju zdolności uczniów w wielu przypadkach zawodzi. Jak zauważa Zbyszko Melosik (2008, s. 17), „Edukacja polska - na poziomie podstawowym i średnim - jest edukacją "zagubionych talentów«, przytłoczonych przez nieuniknione "uprzeciętnianie«". Konieczne wydaje się więc wypracowanie systemowego programu pracy z uczniem zdolnym, uwzględniającego współgranie wielu elementów.

Szczególnego znaczenia nabiera właściwe przygotowanie nauczycieli do pracy i opieki nad uczniami zdolnymi. W wielu krajach europejskich (m.in. Francja, Austria, Słowacja, kraje skandynawskie, Dania) problematyka uzdolnień i form wsparcia ucznia zdolnego uwzględniona została w programie kształcenia nauczycieli na zasadzie obowiązkowej (Gwiazdowska-Stańczak, Sękowski 2018, s. 78-85). Tymczasem w Polsce kwestie te podejmuje się na zasadzie opcjonalnej a decyzje o prowadzeniu zajęć dotyczących zagadnienia zdolności w ramach odrębnego przedmiotu leżą po stronie placówek organizujących kształcenie nauczycieli.

Przedstawione w pracy wyniki badań wskazują również na potrzebę motywowania nauczycieli do większego angażowania się w pracę z uczniem zdolnym oraz doskonalenia ich w tym obszarze. Wydaje się, że wartościowe byłoby opracowanie oferty szkoleń, warsztatów, kursów czy studiów podyplomowych obejmującej zagadnienia związane ze sposobami identyfikowania dzieci i młodzieży zdolnej, rozwijającej kompetencje potrzebne w działaniach dydaktyczno-wychowawczych skierowanych do uczniów zdolnych.

W budowaniu systemów wspierania uczniów zdolnych szkoły powinny korzystać z doświadczeń i pomysłów innych szkół oraz pomocy organizacji i instytucji działających na rzecz uczniów zdolnych, takich jak: Krajowy Fundusz na Rzecz Dzieci, Polska Fundacja Dzieci i Młodzieży, Stowarzyszenie Szkół Twórczych, Fundacja Destination Imagination Polska.

\section{LITERATURA}

Bieluga K., 2003, Nauczycielskie rozpoznawanie cech inteligencji i myślenia twórczego. Kraków, Oficyna Wydawnicza „Impuls”.

Ciechanowski J., Chmielewska B., Czyż E., Kołodziej Z., 2010, Prawo do edukacji dzieci o specjalnych potrzebach edukacyjnych. Raport $z$ monitoringu. Warszawa, Helsińska Fundacja Praw Człowieka. 
Cybis N., Drop E., Rowiński T., Cieciuch J., 2012, Uczeń zdolny - analiza dostępnych narzędzi diagnostycznych. Raport opracowany dla ORE w ramach projektu Opracowanie $i$ wdrożenie kompleksowego systemu pracy z uczniem zdolnym. Warszawa, Ośrodek Rozwoju Edukacji.

Dąbrowska T., Dyndor L., Foryś M., Gałązka K., Kolczyńska E., Madziara A., Pęczek K., Sprawka E., Wachowicz E., 2013, Model pracy z uczniem zdolnym w gimnazjum. Warszawa, Ośrodek Rozwoju Edukacji.

Dyrda B., 2000, Syndrom Nieadekwatnych Osiagnięć jako niepowodzenie szkolne uczniów zdolnych. Diagnoza i terapia. Kraków, Oficyna Wydawnicza „Impuls”.

Dyrda B., 2007, Zjawiska niepowodzeń szkolnych uczniów zdolnych. Rozpoznawanie i przeciwdziałanie. Kraków, Oficyna Wydawnicza „Impuls”.

Dyrda B., 2012, Edukacyjne wspieranie rozwoju uczniów zdolnych: studium społecznopedagogiczne. Warszawa, Wydawnictwo Akademickie Żak.

Fechner-Sędzicka I., 2013, Model pracy z uczniem zdolnym w szkole podstawowej. Jak praktycznie i systemowo zorganizować edukacje uczniów zdolnych na poziomie szkoły podstawowej? Warszawa, Ośrodek Rozwoju Edukacji.

Giza T., 2006, Socjopedagogiczne uwarunkowania procesu identyfikowania oraz rozwoju zdolności uczniów w szkole. Kielce, Wydawnictwo Akademii Świętokrzyskiej.

Gwiazdowska-Stańczak S., Sękowski A.E., 2018, Rodzina uczniów zdolnych. Warszawa, Difin SA.

Hłobił A., 2010, Działalność szkoły we wspomaganiu rozwoju ucznia zdolnego. Kraków, Oficyna Wydawnicza „Impuls”.

Konwencja o prawach dziecka z 1989, 2012, W: P.J. Jaros, M. Michalak (red). Prawa dziecka. Dokumenty Organizacji Narodów Zjednoczonych. Warszawa, Biuro Rzecznika Praw Dziecka, 197-221.

Landau E., 2005, Twoje dziecko jest zdolne. Warszawa, Instytut Wydawniczy Pax.

Lewowicki T., 1980, Kształcenie uczniów zdolnych. Warszawa, Wydawnictwa Szkolne i Pedagogiczne.

Limont W., 2010, Uczeń zdolny. Jak go rozpoznać i jak z nim pracować. Gdańsk, GWP. Limont W., Cieślikowska J., 2004, Czy potrzebna jest pedagogika zdolności? W: W. Limont (red.), Teoria i praktyka edukacji uczniów zdolnych. Kraków, Oficyna Wydawnicza „Impuls”, 31-62.

Łukasiewicz-Wieleba J., Baum A., 2015, Kompleksowe wspieranie uczniów uzdolnionych Program WARS i SAWA. Warszawa, Wydawnictwo Akademii Pedagogiki Specjalnej. Melosik Z., 2008, Edukacja merytokratyczna i społeczne konstrukcje sukcesu życiowego. „Problemy Wczesnej Edukacji”, 1(7), 7-17.

Najwyższa Izba Kontroli, 2007, Informacja o wynikach kontroli opieki nad uczniami szczególnie uzdolnionymi. Warszawa.

Nęcka E., 2005, Inteligencja: geneza, struktura, funkcje. Gdańsk, GWP. 
Piotrowski E., 2001, Pedagogika dzieci zdolnych i uzdolnionych. W: W. Dykcik (red.), Pedagogika specjalna. Poznań, Wydawnictwo Naukowe UAM, Poznań, 327-343. Rozporzadzenie Ministra Edukacji Narodowej i Sportu z dnia 19 grudnia 2001 r., Dz.U. z 2002 r. Nr 3, poz. 28.

Sękowski A.E., 2009, Wybitne zdolności - wyjątkowość czy codzienność? „Czasopismo Psychologiczne", 15(2), 267-276.

Stańczak M., 2009, Zaspokajanie potrzeb ucznia zdolnego w szkole. Olsztyn, Wydawnictwo Uniwersytetu Warmińsko-Mazurskiego.

Tyszkowa M., 1993, Uczeń zdolny. W: W. Pomykało (red.), Encyklopedia pedagogiczna. Warszawa, Fundacja Innowacja, 864-868.

Uszyńska-Jarmoc J., Kunat B., Tarasiuk M.J., 2014, Sukcesy uczniów zdolnych. Fakty - narracje - interpretacje. Białystok, Centrum Kształcenia Ustawicznego w Białymstoku.

\title{
GIFTED STUDENT IN THE REALITY OF THE POLISH SCHOOL
}

\begin{abstract}
The potential of gifted people is a significant resource for every community. That is why it is important that all of the participants of educational process are aware of the categories "abilities" and "gifted student" and their value. The article presents the issues in working with gifted students. The initial part introduces the term and characteristics of a gifted student and draws the attention to the underachievement syndrome in gifted students and asynchronous development. The role and assignments of school are indicated and special support this institution should provide gifted students with. The article also presents the results of research concerning attention to gifted children in polish schools. Finally, the examples of "good practices" which support the measures taken by schools to plan the education of gifted students are presented.
\end{abstract}

Keywords: gifted student, school, teacher, gifted student education, individual education program, individual education course 